\title{
Ground transportation accidents involving two categories of motorcyclists who transport passengers
}

\author{
Acidente de transporte terrestre envolvendo duas modalidades de motociclistas que fazem transporte de passageiros
}

\author{
Alfredo LUCAS-NETO' \\ Kevan Guilherme Nóbrega BARBOSA ${ }^{1}$ \\ Italo de Macedo BERNARDINO' \\ Rilva Suely de Castro Cardoso LUCAS' \\ Sérgio D'ÁVILA'
}

\section{ABSTRACT}

\section{Objective}

The aim of the present cross-sectional study was to analyze the occurrence of ground transportation accidents involving two categories of motorcyclists who transport passengers in a city located in northeastern Brazil: those who work for city hall and those who work for a private transportation firm.

\section{Methods}

Interviews were held with the aid of a questionnaire administered to a probabilistic sample of 210 individuals (125 from city hall and 85 from the private firm).

Results

A high number of motorcyclists in both categories combined (78.6\%) suffered traffic accidents in the 12 months prior to the inquiry. Collisions with automobiles constituted the most frequent type of accident (43.6\%). Accidents were more associated with motorcyclists working for city hall $(p<0.05)$, due mainly to the fact that these individuals had been employed for a longer period of time $(p<0.001)$. The occurrence of bodily injuries was high in both categories (63.6\%). Facial injuries were the least frequent in both categories due mainly to the use of protection equipment (98.2\%).

\section{Conclusion}

The occurrence of traffic accidents was high in the two motorcycle passenger transportation categories analyzed, demonstrating that motorcycles are used to transport passengers in a risky manner.

Indexing terms: Accidents, traffic. Facial Injuries. Motorcycles. Wounds and Injuries.

\section{RESUMO}

\section{Objetivo}

Analisar a ocorrência de acidente de transporte terrestre entre duas modalidades de motociclistas que realizam o transporte de passageiros em um município do Nordeste Brasileiro.

\section{Métodos}

Nesta cidade existem dois grupos de motociclistas regulamentados, um destes trabalhava para prefeitura e outro para uma empresa privada. Foi realizada uma entrevista por meio de um questionário para uma amostra probabilística de 210 sujeitos ( $n=125$ da prefeitura, $n=85$ empresa).

\section{Resultados}

Um elevado número de motociclistas entre as duas modalidades (78,6\%) sofreram acidente de trânsito nos últimos 12 meses à realização do inquérito, sendo a colisão coo o automóvel o tipo mais frequente (43,6\%). Entretanto, a modalidade de motociclistas da prefeitura estiveram mais associados com a presença de acidentes $(p<0,05)$, principalmente pelo fato de estarem trabalhando a mais tempo $(p<0,001)$. A ocorrência de injúrias corporais foi alta $(63,6 \%)$ em ambas as modalidades. Injúrias faciais foram menos frequentes para as duas modalidades analisadas, principalmente devido ao uso do equipamento de proteção $(98,2 \%)$.

\section{Conclusão}

O alto número de motociclistas acidentados entre as duas modalidades de transporte de passageiros, mostra a falta de segurança deste tipo de transporte. Considerando que estes motociclistas realizam o transporte público de passageiros é necessário melhorias na regulamentação e na prevenção de acidentes.

Termos de indexação: Acidente de Trânsito. Motocicletas. Ferimentos e lesões. Traumatismos faciais.

\footnotetext{
${ }^{1}$ Universidade Estadual da Paraíba, Departamento de Odontologia. Av. das Baraunas, 351, Bairro Universitário, 58429-500, Campina Grande, PB, Brasil. Correspondência para / Correspondence to: S D’AVILA. E-mail: <davila2407@hotmail.com>.
} 


\section{INTRODUCTION}

Motorcycles constitute one of the most dangerous means of transportation among all types of motor vehicles. Riders are vulnerable to accidents that can result in injury or death ${ }^{1-2}$. This situation is particularly aggravated in lowincome countries, as factors such as the intense traffic flow; deficient public transportation services and the lack of exclusive lanes for motorcycles place this category of motor vehicle operators at greater risk ${ }^{3}$.

Based on data from the Brazilian National Registry of Motor Vehicles of the Department of Transportation report, the country had a total of 2,542,732 motorcycles in 1998. By 2007, this number had risen to $9,410,110$. Moreover, the number of deaths due to traffic accidents involving motorcycles increased significantly between 1998 to 2008 (754\%), which is a much higher figure in comparison to other categories of transportation, such as occupants of automobiles (100\% increase) and truck transportation (200\% increase), in the same ten-year period ${ }^{4}$.

Accident victims involving motorcycles are the most vulnerable to injuries to the body and face ${ }^{5-8}$, especially riders who do not use individual protection equipment. Moreover, motorcycles are used as a means of passenger transportation in Brazil, denominated "mototaxis". In 2009, the Brazilian government passed regulations governing this type of transportation through Federal Law n. 12009/099.

However, the safety of mototaxis is highly questionable and investigations are needed to address this issue adequately. The law requires that the driver be at least 21 years old and have at least 2 years of driving experience with motorcycles in order to qualify for professional practice ${ }^{10}$.

In emerging countries, such as Brazil, this type of transport is common. Although these studies describe accidents on motorcycles, there is a lack of research on the drivers that work with motorcycles carrying passengers. Further, this study will explore that this type of transport is dangerous and that laws should be applied.

The city where the study was performed has a high number of motorcycles as well as a high number of accidents involving these vehicles. The aim of the present study was to analyze the occurrence of ground transportation accidents involving two categories of regulated motorcyclists who transport passengers in a medium-sized city located in northeastern Brazil.

\section{METHODS}

\section{Study location}

The city analyzed is part of a metropolis in northeastern Brazil, with a population of 687,545 inhabitants and three basic types of public transportation: bus, taxi and mototaxi. Like taxis, mototaxis transport passengers and are used due to their greater agility on urban streets in comparison to other forms of transportation.

\section{Sample, study design and interview}

A cross-sectional study was carried out between August and October 2012 with professional motorcyclists in the region. The city has three categories of mototaxi: 1) motorcyclists who work for the city hall $(n=727) ; 2$ ) motorcyclists who work for a private transportation firm ( $n=308$ ); and 3) clandestine motorcyclists. The latter group was excluded from the study, as these individuals are not regulated to exercise the profession and many work sporadically. Among the universe of motorcyclists eligible for the study $(n=1035)$, probabilistic sampling was performed, leading to a sample of 210 subjects based on a $5 \%$ level of significance, $95 \%$ confidence interval, a 50 $\%$ expected prevalence for injury and expected $20 \%$ rate of data loss. A list of names of motorcyclists who work for city hall and the private firm was generated and the subjects were selected randomly with the aid of the EpiInfo program. Category of mototaxi drivers was considered as a dependent variable (city hall / private transportation firm).

The motorcyclists selected answered a questionnaire addressing socio-demographic variables, characteristics related to the occurrence of traffic accidents and injuries to the body and face in the previous 12 months. The interviews were scheduled through telephone contacts. The decline rate was less than $2 \%$. No benefits were promised to the individuals who agreed to participate. Administration of the questionnaire took an average of 10 minutes. This study received approval from a Human Research Ethics Committee (process number: 0091.0.133.000-11) and was carried out in compliance with national (Resolution 196/96) and international (Declaration of Helsinki) norms governing studies involving human subjects. The recommendations were explained in "STROBE Statement".

\section{Statistical analysis}

The data were analyzed using analytical statistics [Fisher's exact test, Pearson's chi-squared test and 
Prevalence Ratio (PR)]. The level of significance was set to $5 \%(p<0.05)$ for all analyses. The SPSS for Windows (version 20.0, SPSS Inc., Chicago, Illinois, USA) was employed for the statistical analysis.

\section{RESULTS}

A total of 210 of motorcyclists were analyzed. All study participants were men ( $N=210)$, among whom 165 (78.6\%) had at least one type of traffic accident in the past 12 months. Table 1 displays the socio-demographic characteristics of the motorcyclists.

The study participants were Married (77.6\%), had 8 years of education (57.1\%), and had lived in the central region (88.1\%). There was a statistically significant association between these variables: have other job (73.3 \%) and duration of service 11 years or more and the occurrence (Table 1).

Table 2 displays the distribution of traffic accidents among motorcyclists, whom 165 (78.6\%) had at least one type of traffic accident in the last 12 months. Most accidents $(43.6 \%)$ were collision with a car. Most occurrences were on Saturday (20.3), the time of occurrence of 12:00 to 17:59 (35.2\%). Most motorcyclists do not ingested alcohol (93.9\%) and wore a full-face helmet (98.2\%).

Facial injuries occurred in 15 cases $(9.1 \%)$, these victims, most injuries were the forehead (33.3\%) and soft tissue injuries were to the most prevalent types (53.3\%). Most victims did not require hospitalization due to trauma $(61.2 \%)$ and those who were hospitalized required a period of up to 24 hours (Table 3 ).

Table 1. Distribution of sociodemographic characteristics of motorcyclists.

\begin{tabular}{|c|c|c|c|c|c|}
\hline \multirow[b]{3}{*}{ Variables } & \multicolumn{3}{|c|}{ Categories of motorcyclists } & \multirow{3}{*}{$p$-value } & \multirow{3}{*}{ PR $(95 \% \mathrm{Cl})$} \\
\hline & City hall & Private firm & Total & & \\
\hline & n (\%) & n (\%) & n (\%) & & \\
\hline 18 to 25 & $5(4.0)$ & $12(14.1)$ & $17(8.1)$ & $p(1)=0.007^{*}$ & 1 \\
\hline 26 to 35 & $34(27.2)$ & $32(37.6)$ & $66(31.4)$ & & $2.55(0.81-8.05)$ \\
\hline 46 to 55 & $21(16.8)$ & $10(11.8)$ & $31(14.8)$ & & $5.04(1.39-18.25)$ \\
\hline 56 or older & $15(12.0)$ & $3(3.5)$ & $18(8.6)$ & & $12.00(2.37-60.65)$ \\
\hline \multicolumn{6}{|l|}{ Marital status } \\
\hline Single & $26(20.8)$ & $21(24.7)$ & $47(22.4)$ & $p(1)=0.505$ & 1 \\
\hline Married & $99(79.2)$ & $64(75.3)$ & $163(77.6)$ & & $1.25(0.65-2.41)$ \\
\hline$>8$ years & $31(24.8)$ & $16(18.8)$ & $47(22.4)$ & & $2.03(0.87-4.75)$ \\
\hline \multicolumn{6}{|l|}{ Place of residence } \\
\hline Central region & $113(90.4)$ & $72(84.7)$ & $185(88.1)$ & $p(2)=0.143$ & ** \\
\hline Metropolitan region & $5(4.0)$ & $2(2.4)$ & $7(3.3)$ & & $\star \star$ \\
\hline Other city & $7(5.6)$ & $11(12.9)$ & $18(8.6)$ & & ** \\
\hline \multicolumn{6}{|l|}{ Has other job } \\
\hline Yes & $25(20.0)$ & $31(36.5)$ & $56(26.7)$ & $p(1)=0.008^{*}$ & 1 \\
\hline No & $100(80.0)$ & $54(63.5)$ & $154(73.3)$ & & $2.30(1.23-4.28)$ \\
\hline
\end{tabular}


Table 2. Distribution of traffic accidents among motorcyclists.

\begin{tabular}{|c|c|c|c|c|c|}
\hline \multirow{2}{*}{ Variables } & \multicolumn{3}{|c|}{ Categories of motorcyclists } & \multirow[b]{2}{*}{$p$-value } & \multirow[b]{2}{*}{ PR (95\% Cl) } \\
\hline & City hall & Private firm & Total & & \\
\hline \multicolumn{6}{|l|}{$\begin{array}{l}\text { Motorcycle accident in } \\
\text { previous } 12 \text { months }\end{array}$} \\
\hline Yes & $104(83.2)$ & $61(71.8)$ & 165(78.6) & $\mathrm{p}^{(1)}=0.047^{*}$ & $1.95(1.00-3.79)$ \\
\hline No & $21(16.8)$ & $24(28.2)$ & $45(21.4)$ & & 1 \\
\hline \multicolumn{6}{|l|}{ Type of accident } \\
\hline Collision with bus/truck & $4(3.8)$ & $1(1.6)$ & $5(3.0)$ & & ** \\
\hline $\begin{array}{l}\text { Collision with other } \\
\text { motorcycle }\end{array}$ & $8(7.7)$ & $8(13.1)$ & $16(9.7)$ & & ** \\
\hline Run over & $4(3.8)$ & - & $4(2.4)$ & & ** \\
\hline Other & $4(3.8)$ & $3(4.9)$ & $7(4.2)$ & & ** \\
\hline \multicolumn{6}{|l|}{ Day of occurrence ${ }^{(3)}$} \\
\hline Friday & $12(17.9)$ & $5(9.8)$ & $17(14.4)$ & & $2.40(0.57-10.04)$ \\
\hline Saturday & $14(20.9)$ & $10(19.6)$ & $24(20.3)$ & & $1.40(0.39-5.00)$ \\
\hline Sunday & $12(17.9)$ & $4(7.8)$ & $16(13.6)$ & & $3.00(0.67-13.40)$ \\
\hline \multicolumn{6}{|l|}{ Time of occurrence ${ }^{(4)}$} \\
\hline $00: 00$ to $05: 59$ & $6(6.1)$ & $4(6.6)$ & $10(6.3)$ & $\mathrm{p}^{(1)}=0.470$ & 1 \\
\hline $06: 00$ to $11: 59$ & $33(33.7)$ & $14(23.0)$ & $47(29.6)$ & & $1.57(0.38-6.44)$ \\
\hline $12: 00$ to $17: 59$ & $34(34.7)$ & $22(36.1)$ & $56(35.2)$ & & $1.03(0.26-4.07)$ \\
\hline $18: 00$ to $23: 59$ & $25(25.5)$ & $21(34.4)$ & $46(28.9)$ & & $0.79(0.20-3.19)$ \\
\hline \multicolumn{6}{|l|}{ Ingestion of alcohol } \\
\hline Yes & $9(8.7)$ & $1(1.6)$ & $10(6.1)$ & $\mathrm{p}^{(2)}=0.093$ & ** \\
\hline No & $95(91.3)$ & $60(98.4)$ & $155(93.9)$ & & \\
\hline \multicolumn{6}{|l|}{ Use of full-face helmet } \\
\hline
\end{tabular}

Note: $\mathrm{PR}=$ prevalence ratio; $\mathrm{Cl}=$ confidence interval; ${ }^{\star}$ Significant difference at $5.0 \%$ level; ${ }^{*}$ Undetermined due to very low frequency of occurrence; ${ }^{1}$ Pearson's chi-squared test; ${ }^{2}$ Fisher's exact test; ${ }^{3}$ Data missing from 47 respondents; ${ }^{4}$ Data missing from 6 respondents.

\section{DISCUSSION}

Among the total sample of motorcyclists interviewed $(n=210), 78.6 \%(n=165)$ had suffered an accident in the previous 12 months. Another study carried out in Brazil involving 301 victims of ground transportation accidents also found a high prevalence rate of accidents involving motorcyclists $(67.3 \%)^{11}$. A survey conducted in the southern region of Brazil involving 3643 victims of ground transportation accidents found a lower prevalence rate $(44.4 \%)$; nonetheless, motorcycles were the main type of vehicle involved in cases of accidents ${ }^{5,12-13}$.

These data are worrisome and highlight the low degree of safety motorcycles offer ${ }^{14}$. Indeed, the lack of body protection makes riders more vulnerable to trauma and the lasting effects of this trauma. However, it is necessary considerer that mototaxi drivers are commercial workers, not occasional driver, incorporating the longer and continuous driving duration of commercial group into consideration.

The socio-demographic characteristics of the sample demonstrate that most of the motorcyclists interviewed were young. Moreover, the 26-to-35-yearold age group in both categories (those who worked for city hall and those who worked for a private firm) was significantly involved in accidents. Previous studies have described a greater frequency of motorcycle accidents involving young people ${ }^{15-17}$. In the present study, the occurrence of accidents among young people was higher regardless of the work category. A possible explanation for 
Table 3. Distribution of accidents associated with trauma.

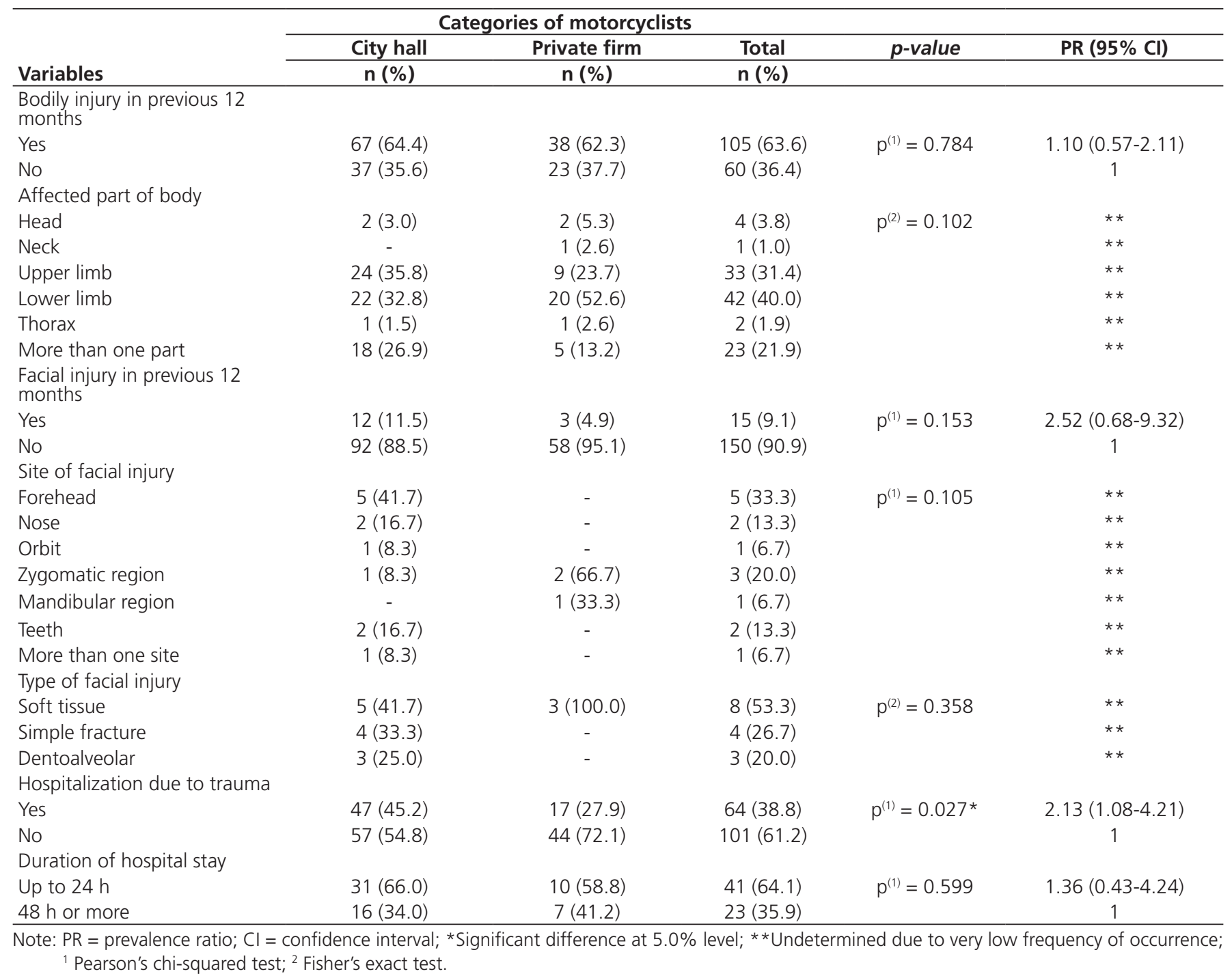

this finding is that young adults are more socially active than adults in other age groups, which makes them more susceptible to traffic accidents ${ }^{13}$. Moreover, young people are more vulnerable to traffic accidents due to their lesser maturity, feelings of omnipotence, relative inexperience at riding a motorcycle and greater risk-taking in traffic ${ }^{8}$.

All motorcyclists were men; the majority was married, had up to eight years of schooling and resided within the city analyzed. However, these variables were not associated with the work modality. Men are recognized as the main victims of traffic violence ${ }^{18-23}$. In Brazil, a large number of males with a low socioeconomic status grow up in a culture that stresses a need for social identification and owning objects of value ${ }^{24}$. A motorcycle is an example of an object that represents value for these individuals, especially due to its popularization and lower purchasing cost in comparison to automobiles, making it more accessible to poorer individuals.

Working for a private transportation firm was associated with having a second job. It is possible that this second job serves to supplement the employee's salary. This finding may also be related to the fact that city hall does not allow its employees to have any other type of paid work. Moreover, motorcyclists who worked for city 
hall had a longer time on the job in comparison to those who worked for the private firm $(p<0.001)$. This likely gives municipal employees greater experience at riding a motorcycle. However, there is a tendency for professionals involved in passenger transportation to acquire more risky forms of driving over the years ${ }^{25}$.

Motorcyclists working for city hall were more involved in accidents in comparison to those working for the private firm. This finding may be related to the longer time of service among city hall employees, which makes them more susceptible to traffic accidents. No other accident characteristics were significantly associated with the transportation modality in the present study. The most frequent type of accident was collision with an automobile, followed by falls. Despite the relatively high number of motorcyclists who had suffered the latter, many riders do not consider a fall to constitute an accident. The greater occurrence of accidents during the day was likely related to the fact that motorcyclists generally do not work at night.

Few interviewees in either category reported alcohol intake prior to traffic accidents. This is a positive finding, as alcohol is an important factor in the occurrence of accidents involving motorcyclists $26-27$. Another positive finding was the use of individual protection equipment (full-face helmet) by the majority of interviewees. A study carried out in Iran with a sample of 6010 motorcyclists found that only $10 \%$ wore a standard helmet ${ }^{28}$. A systematic review of the literature reports that the use of a helmet reduces the risk of death and injuries to the head and face during traffic accidents ${ }^{7}$.

Motorcyclists involved in traffic accidents suffered injuries to both the body (63.6\%) and face (9.1\%). The most affected parts of the body were the lower limbs (42\%) and upper limbs (33\%). In a study carried out in Thailand involving 3650 cases of traffic accidents, the authors also found the upper and lower limbs to be the parts of the body most affected in accidents involving motorcyclists ${ }^{29}$. In an investigation carried out in Brazil involving 430 motorcyclists treated at the emergency ward of a hospital, the lower limbs were the most affected (55\% of cases), followed by the face $(52.2 \%)^{8}$.

In the present study, the prevalence of facial injuries was low due to the use of individual protection equipment (full-face helmet) at the time of the accident. The city where the study was conducted has efficient supervision. Due to this factor and fearing fines, hardly a driver is caught traveling by motorcycle on public roads without a helmet. The analysis of facial injuries revealed that the most affected sites were soft tissues of the forehead (33.3\%), zygomatic region (20\%) and nose $(13.3 \%)$ as well as dental tissues (13.3\%).

In a previous study carried out in Brazil involving 530 victims of maxillofacial injuries, soft tissues were affected in $98 \%$ of cases ${ }^{6}$. The prevalence rate of soft tissue injuries was $53.3 \%$. Soft tissues represent the first line of defense against injuries and trauma. In cases with extensive trauma, bone tissue can be compromised, leading to facial fractures and dentoalveolar trauma. Such cases were less frequent in comparison to soft tissue injuries in the present study.

Facial injuries normally require hospitalization and present the possibility of facial deformities. This length of hospitalization suggests the involvement of lesions requiring treatments that are more complex; otherwise, drivers would have been discharged a few hours after the initial treatment ${ }^{10}$.

In both work modalities, accident victims needed to be hospitalized due to the trauma sustained ( $p=$ 0.027). No statistically significant difference in "duration of hospital" stay was found between the two categories. The need for hospitalization suggests a more severe traffic accident, which could have negative consequences for these workers, as trauma can result in deformity in the physiognomy of the face as well as emotional scars ${ }^{30}$.

One limitation of this study was possible recall bias of victims, a bias that is not present in studies that use medical records.

\section{CONCLUSION}

The results suggest that the occurrence of traffic accidents during the last 12 months prior to the study was high between both categories of motorcyclists (those who worked for city hall and those who worked for a private firm). The socio-demographic characteristics of the sample demonstrated that most of the motorcyclists interviewed were young men, who had a low level of schooling.

The victims suffered injuries to the body as well as to the face, and the lower limbs corresponded to the body region most affected. In addition, the victims of two types of riders had to be hospitalized due to trauma, but there was no association between lengths of hospital stay. The findings highlight the risk of injuries related to motorcyclists who transport passengers. 


\section{Collaborators}

A LUCAS-NETO prepared the development of the study protocol, the design of the method, data analysis, and interpretation of results and wrote the paper. KGN BARBOSA participated in data analysis, interpretation of results, contributed to the revision of the paper and approved the final version. IM BERNARDINO participated in the development of the study protocol, performed the

\section{REFERENCES}

1. Cheng AS, Ng TG, Lee HC. A comparison of the hazard perception ability of accident-involved and accident-free motorcycle riders. Accid Anal Prev. 2011;43 (4):1464-71. doi: 10.1016/j.aap.2011.02.024

2. Clarke DD, Ward P, Bartle C, Truman W. The role of motorcyclist and other driver behaviour in two types of serious accident in the UK. Accid Anal Prev. 2007;39(5):974-81. doi:10.1016/j. aap.2007.01.002

3. Ameratunga S, Hijar $M$, Norton, R. Road-traffic injuries: confronting disparities to address a global-health problem. Lancet. 2006;367(9521):1533-40. doi: 10.1016/S01406736(06)68654-6

4. National Council of Health Secretaries. Violence on traffic: epidemic deaths of motorcyclists worries the public health. J CONASS. 2009;42(1):13-6.

5. Andrade SM, Mello Jorge MHP. Victims' characteristics by road accidents in a city of Southern Brazil. Rev Saude Publica. 2000;34(2):149-56. doi: 10.1590/S003489102000000200008

6. Leles JL, dos Santos EJ, Jorge FD, da Silva ET, Leles CR. Risk factors for maxillofacial injuries in a Brazilian emergency hospital sample. J Appl Oral Sci. 2010;18(1):23-9. doi: 10.1590/S1678-77572010000100006

7. Liu BC, Ivers R, Norton R, Boufous S, Blows S, Lo SK. Helmets for preventing injury in motorcycle riders. Cochrane Database Syst Rev. 2008;23(1):CD004333. doi: 10.1002/14651858. CD004333.pub3

8. Santos AM, Moura ME, Nunes BM, Leal CF, Teles JB. Profile of motorcycle accident victims treated at a public hospital emergency department. Cad Saude Publica. 2008;24(8):192738. doi: 10.1590/S0102-311X2008000800021

9. Brasil. Lei n. 12.009, de 29 de Julho de 2009. Regulamenta o exercício das atividades dos profissionais em transporte de passageiros, "mototaxista", em entrega de mercadorias e em serviço comunitário de rua, e "motoboy", com o uso de motocicleta, altera a Lei no 9.503, de 23 de setembro de 1997, para dispor sobre regras de segurança dos serviços de transporte remunerado de mercadorias em motocicletas data collection, contributed to the revision of the paper and approved the final version. RSCC LUCAS and S D'AVILA participated in the study protocol development, design method, analyzed the data, interpreted the results, and performed the critical review of paper for final approval. e motonetas - moto-frete -, estabelece regras gerais para a regulação deste serviço e dá outras providências [online]. Diário Oficial da Republica Federativa do Brasil, Brasília (DF): 2009, jul 29 [citado 2014 mar 13]. Disponível em: <http://www. planalto. gov.br/ccivil_03/_Ato2007-2010/2009/Lei/L12009.htm>.

10. Barbosa KGN, Lucas-Neto A, Gama DG, Lima-Neto JC. Lucas RSCC, d'Avila S. Injuries and absenteeism among motorcycle taxi drivers who are victims of traffic accidents. J Forensic Leg Med. 2014;26:15-18. doi: 10.1016/j.jflm.2014.03.008

11. Caixeta CR, Minamisava R, Oliveira LM, Brasil VV. Traffic injuries among youth in Goiânia, Goiás State. Cien Saude Colet. 2009;14(5):1807-15. doi: 10.1590/S141381232009000500022

12. Chrcanovic BR, Abreu MH, Freire-Maia B, Souza LN. 1,454 mandibular fractures: a 3-year study in a hospital in Belo Horizonte, Brazil. J Craniomaxillofac Surg. 2012;40(2):116-23. doi: 10.1016/j.jcms.2011.03.012

13. Henfy AF, Barss P, Eid HO, Abu-Zidan FM. Motorcyclerelated injuries in the United Arab Emirates. Accid Anal Prev. 2012;49:245-8. doi: 10.1016/j.aap.2011.05.003

14. Jung S, Xiao Q, Yoon Y. Evaluation of motorcycle safety strategies using the severity of injuries. Accid Anal Prev. 2013;59:357-64. doi: 10.1016/j.aap.2013.06.030

15. Atilgan S, Erol B, Yaman F, Yilmaz N, Ucan MC. Mandibular fractures: a comparative analysis between young and adult patients in the southeast region of Turkey. J Appl Oral Sci. 2010;18(1):17-22. doi: 10.1590/\$1678-77572010000100005

16. Sauer MTN, Wagner MB. Fatal traffic accidents and their association with the infant mortality rate and adolescence. Cad Saude Publica. 2003;19(5):1519-26. doi: 10.1590/S0102$311 \times 2003000500030$

17. Bormann KH, Wild $S$, Gellrich NC, Kokemüller $H$, Stühmer $C$, Schmelzeisen $R$, et al. Five-year retrospective study of mandibular fractures in Freiburg, Germany: incidence, etiology, treatment, and complications. J Oral Maxillofac Surg. 2009;67(6):1251-5. doi: 10.1016/j.joms.2008.09.022

18. Carvalho TB, Cancian LR, Marques CG, Piatto VB, Maniglia JV, Molina FD. Six years of facial trauma care: an epidemiological analysis of 355 cases. Braz J Otorhinolaryngol. 2010;76(5):56574. doi: 10.1590/\$1808-86942010000500006 
19. Chandra-Shekar BR, Reddy C. A five-year retrospective statistical analysis of maxillofacial injuries in patients admitted and treated at two hospitals of Mysore city. Indian J Dent Res. 2008;19(4):304-8. doi: 10.4103/0970-9290.44532

20. Erdmann $D$, Follmar $K E$, Debruijn $M$, Bruno $A D$, Jung $S H$, Edelman $D$, et al. A retrospective analysis of facial fracture etiologies. Ann Plast Surg. 2008;60(4):398-403. doi: 10.1097/ SAP.0b013e318133a87b

21. Lee KH, Snape L, Steenberg LJ, Worthington J. Comparison between interpersonal violence and motor vehicle accidents in the aetiology of maxillofacial fractures. ANZ J Surg. 2007;77(8):695-8. doi: 10.1111/j.1445-2197.2007.04189.x

22. Maliska MC, Lima-Júnior SM, Gil JN. Analysis of 185 maxillofacial fractures in the state of Santa Catarina, Brazil. Braz Oral Res. 2009;23:268-74. doi: 10.1590/S1806-83242009000300008

23. Matos FP, Arnez MF, Sverzut CE, Trivellato AE. A retrospective study of mandibular fracture in a 40-month period. Int J Oral Maxillofac Surg. 2010;39(1):10-5. doi: 10.1016/j. ijom.2009.10.005

24. Montenegro MM, Duarte EC, Prado RR, Nascimento AF. Mortality of motorcyclists in traffic accidents in the Brazilian Federal District from 1996 to 2007. Rev Saude Publica. 2011;45(3):52938. doi: 10.1590/S0034-89102011000300011

25. Veronese AM, Oliveira DLLC. Traffic accidents from the motorcycle couriers' perspective: feedback for health promotion. Cad Saude Publica. 2006;22(12):2717-21. doi: 10.1590/S0102-311X2006001200021
26. De Boni R, Bozzetti MC, Hilgert J, Sousa $T$, von Diemen $L$, Benzano D, et al. Factors associated with alcohol and drug use among traffic crash victims in southern Brazil. Accid Anal Prev. 2011;43(4):1408-13. doi: 10.1016/j.aap.2011.02.016

27. Huang WS, Lai CH. Survival risk factor for fatal injured car and motorcycle drivers in single alcohol-related and alcoholunrelated vehicle crashes. Accid Anal Prev. 2011;42(3):93-9. doi: 10.1016/j.jsr.2011.01.005

28. Zamani-Alavijeh F, Bazargan M, Shafiei A, Bazargan-Hejazi S. The frequency and predictors of helmet use among Iranian motorcyclists: A quantitative and qualitative study. Accid Anal Prev. 2011;43(4):1562-9. doi: 10.1016/j.aap.2011.03.016

29. Yongchaitrakul T, Juntakarn C, Prasartritha T. Socieconimic inequality and road traffic accidents in Thailand: comparing cases treated in government hospitals inside and outside of Bangok. Southeast Asian J Trop Med Public Health. 2012;43(3):785-94.

30. Islam S, Ahmed M, Walton GM, Dinan TG, Hoffman GR. The prevalence of psychological distress in a sample of facial trauma victims. A comparative cross-sectional study between UK and Australia. J Craniomaxillofac Surg. 2012;40(1):82-5. doi: 10.1016/j.jcms.2011.01.014 